\title{
SAR and Pharmacophore Based Designing of Some Antimalarial and Antiretroviral Agents: An INTERNET Based Drug Design Approach
}

\author{
Soumendranath Bhakat* \\ Department of Pharmaceutical Sciences \\ Birla Institute of Technology \\ Mesra, Ranchi-835215 INDIA
}

Received: April 26, $2012 \quad$ Accepted: December 30. 2012

\begin{abstract}
With the development of computational chemistry and molecular docking studies, Structure Activity Relationship or SAR- and pharmacophore-based drug design have been modified to target based drug discovery using sophisticated computational tools which is not very much user friendly and has got many incompatibility issues with many operating systems (OS) and other system configurations. In this paper SAR and pharmacophore based drug design approaches have been described by the used of free internet based tools which are very much user friendly and can almost compatible with any platform. Some antimalarial. And anti retroviral agents have been designed using pharmacophore study and their drug like properties, toxicity, metabolic sites and other parameters are predicted by the free internet based tools.
\end{abstract}

\section{INTRODUCTION}

In recent years computer-aided drug [1-4] design has become an important tool for rational drug design on the basis of SAR (Structure Activity Relationship) and pharmacophore study. The SAR and pharmacophore-based drug design [5-6] is mainly based on Lipski's rule of five.[7] But the high cost of the necessary computational software, its lengthy and complicated installation, and system compatibility issues all make SAR-proficient software difficult for general undergraduate students to handle. Most of these software packages are compatible with LINUX and previous WINDOWS versions (XP, 98, etc.) but are incompatible with the WINDOWS 7 operating system, especially the 64 bit OS. SAR-proficient software requires compilation and a lengthy installation procedure, and these packages also show certain incompatibility issues with INTEL second generation processors (i3, i5, i7, etc.).

To handle these difficulties in order to make drug design easier and convenient, internet-based drug design on the basis of SAR and pharmacophores has become a useful tool for modern structure-based

*Email:soumendranath2009@gmail.com rational drug design. These internet-based tools are easy to handle because they use JAVA to input structure and calculate the drug likeness and molecular properties in real time. These JAVA based internet tools can be applied to predict the toxicity, solubility, pKa, and Lipnski's five rule-all important parameters for structure-based rational drug design.

Recently structural analogue-based drug discovery has become an important tool for designing more potent drugs. This paper uses SAR, pharmacophore study, and structural analogue-based novel drugs to design antimalarial anti-retroviral molecules using internet-based tools.

\section{MATERIALS AND METHODS}

The structural analogue based drug design has been performed using MOLSOFT, in which molecules' in-silico drug likenesses and molecular property prediction tool are important.[8] The new molecules, designed on the basis of SAR and pharmacophore study, were then inputted into a JME molecular editor [9] to allow different properties to be calculated. The lazar toxicity of all these designed drugs have been performed using in-silico internetbased lazar toxicity prediction tools.[10] The 


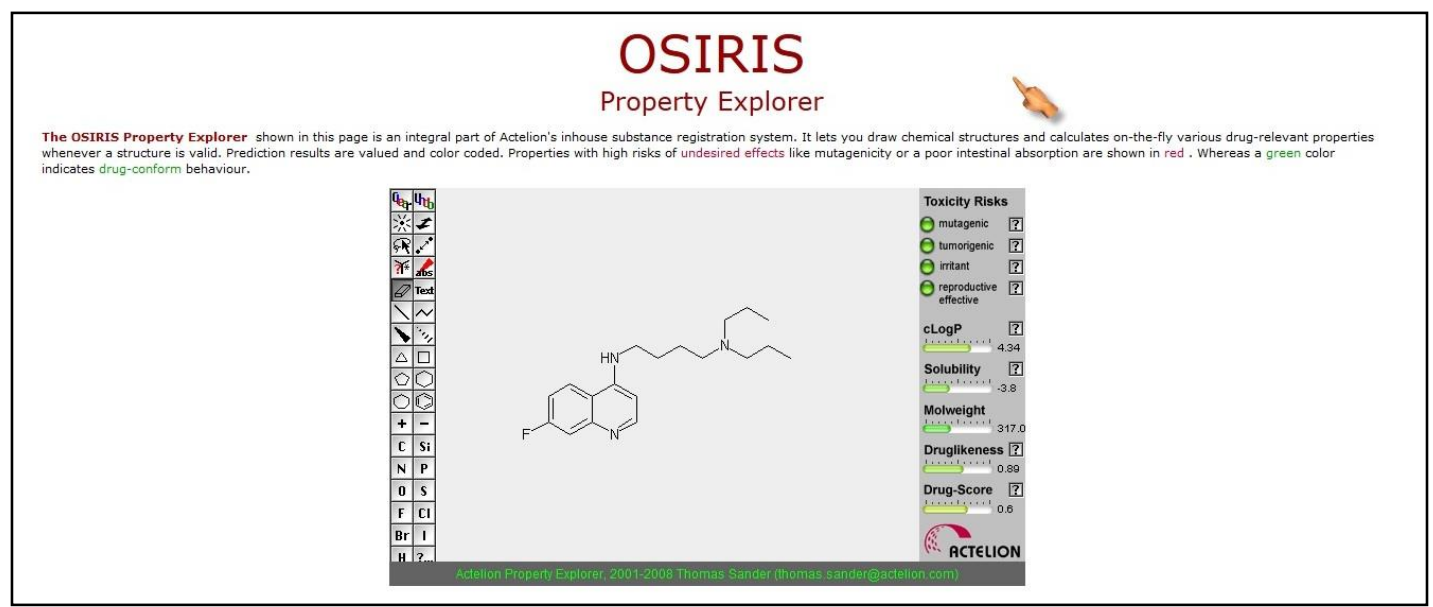

Figure 1. Screenshot of OSIRIS Property Explorer.

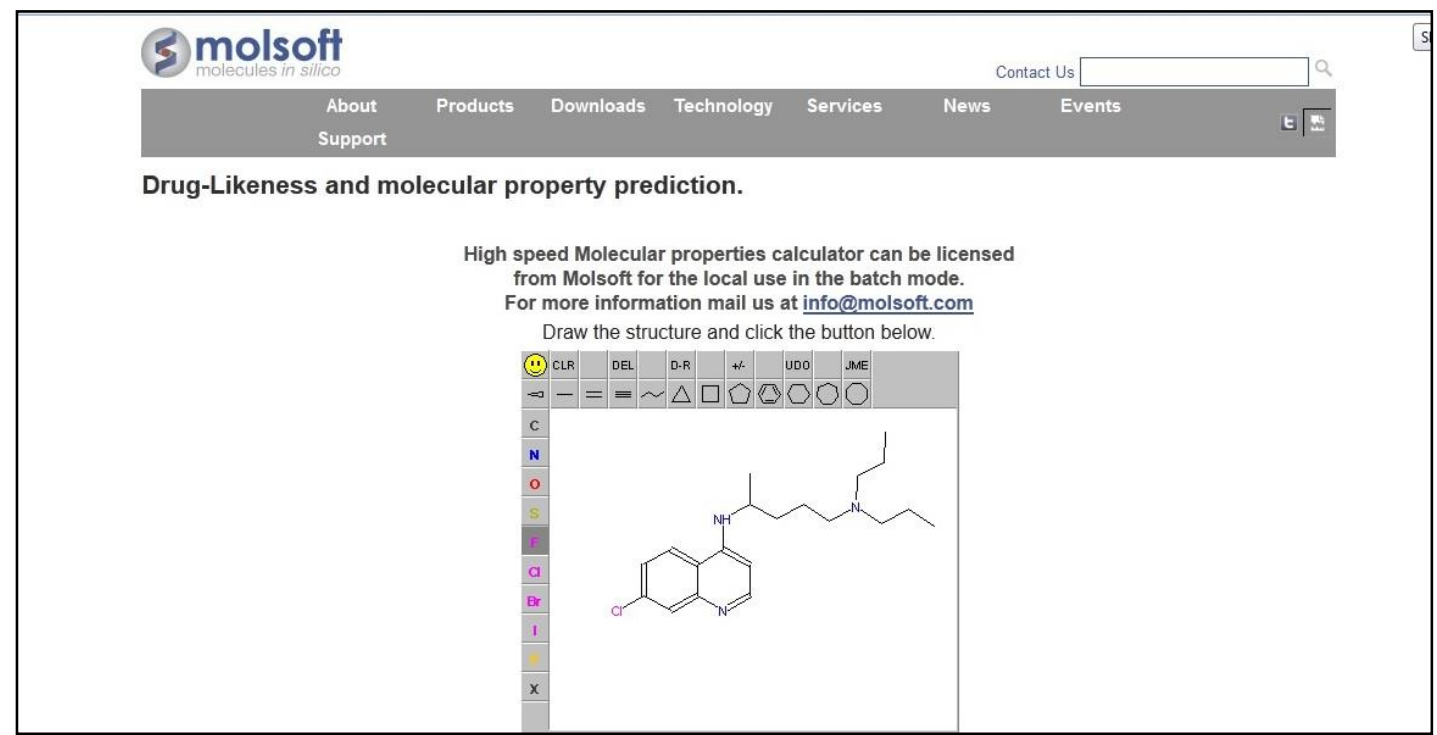

Figure 2. Screenshot of MolSoft Drug likeness and Molecular Property prediction tool.

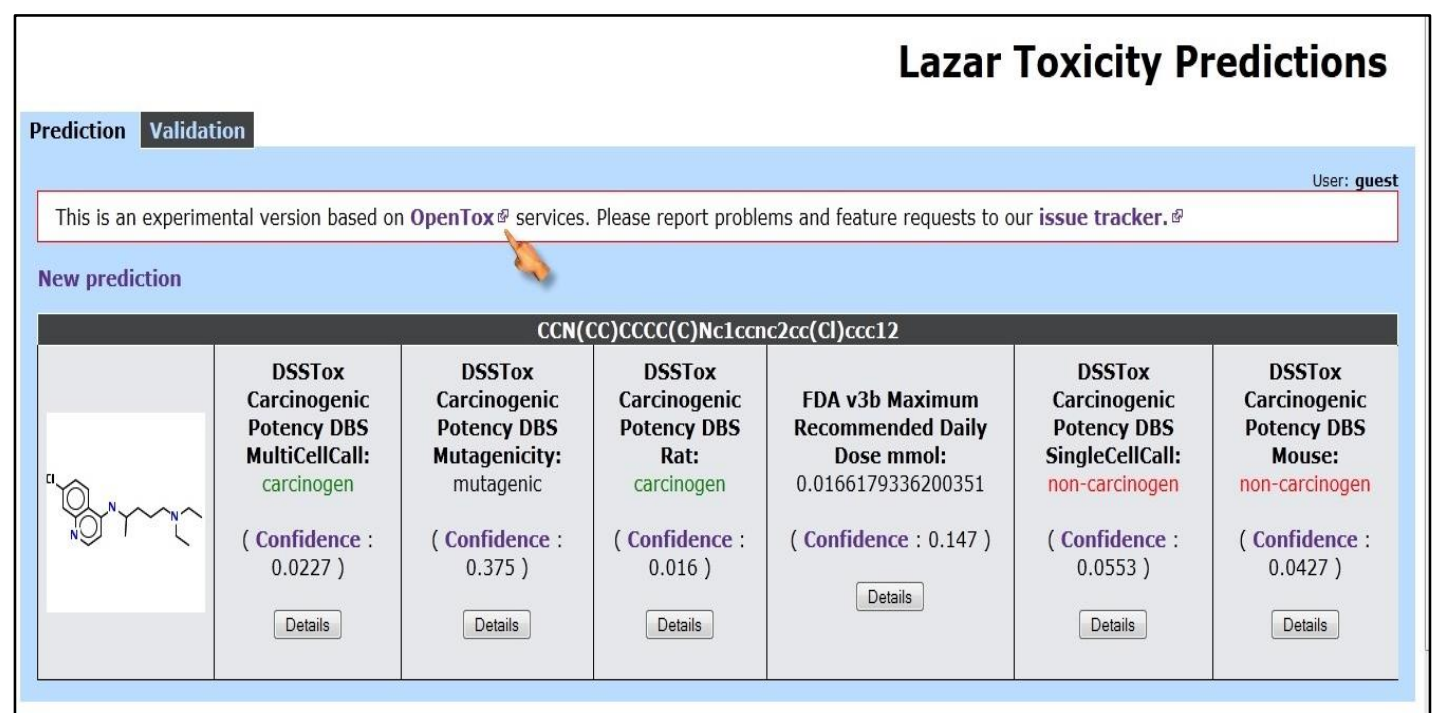

Figure 3. Screenshot of Lazar toxicity prediction tool. 


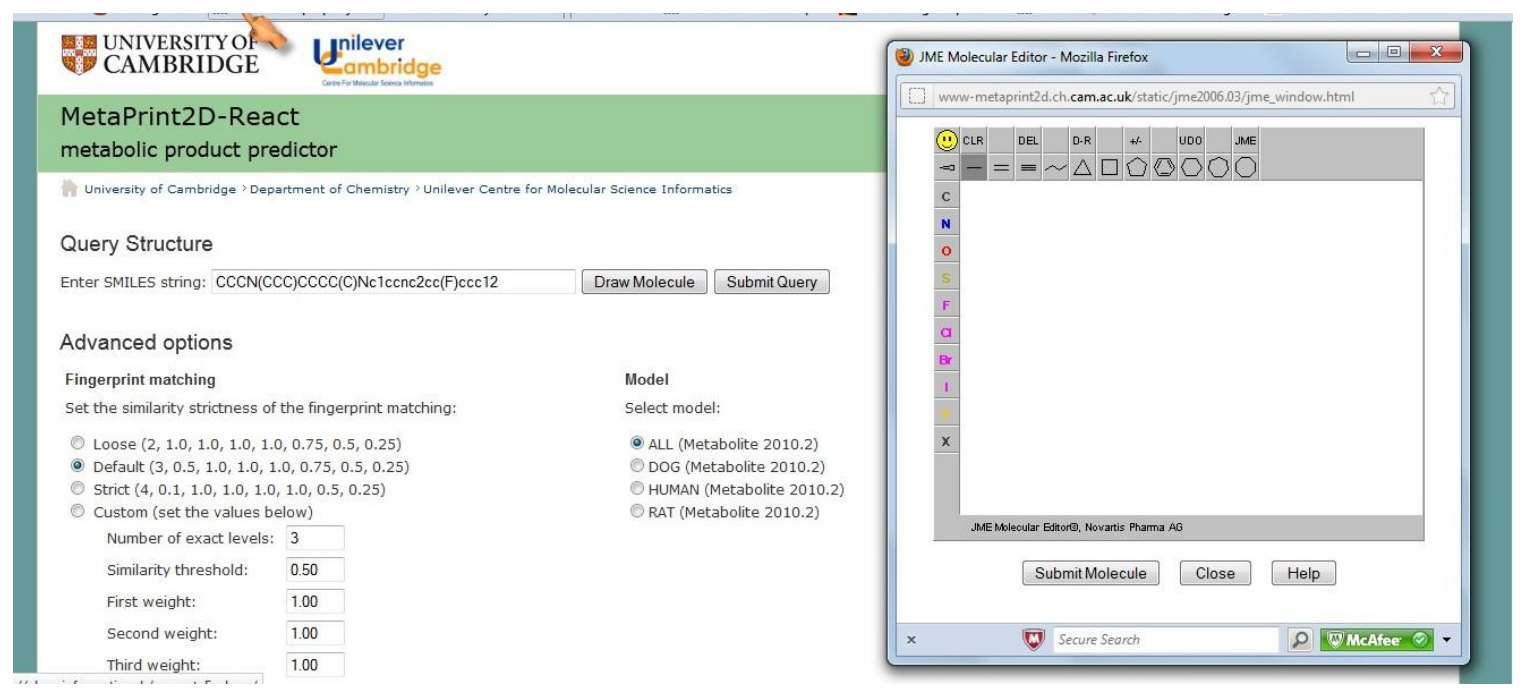

Figure 4. Screenshot of MetaPrint2D metabolic site prediction tool.

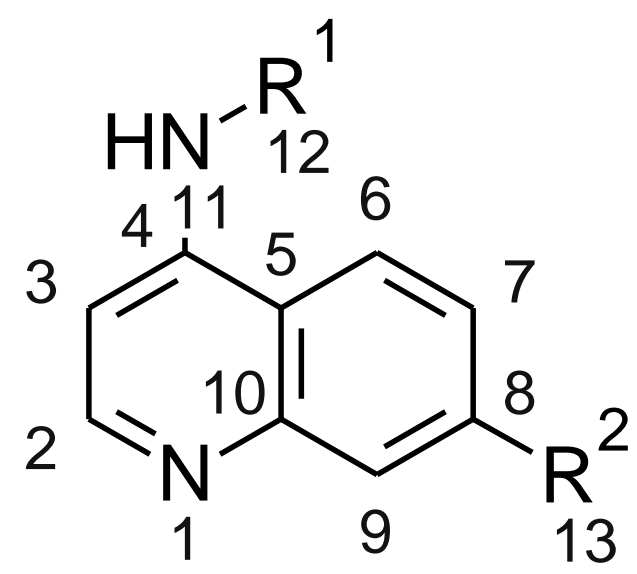

Figure 5. The 4-Amino quinolone pharmacophore, $R^{1}, R^{2}=$ positions of substitution.

OSIRIS Property Explorer [11] was also used to predict toxicity and other drug-like properties. The metabolic sites of these designed drugs have been predicted using MetaPrint2D. [12] All these calculations were performed using a WINDOWS 7 64-bit operating system having Intel Core 2 duo processor.

III. Results and Discussions

a. Designing of New Chloroquine structural analogues as probable antimalarial agents

Inexpensive and stable antimalarial drugs such as the chloroquine [13] have kept malaria in check in most regions for decades. However, the rise in malaria deaths is due in part to the diseases' increased resistance to chloroquine [14], hence there is a necessity to design some more potent 4 aminoquinoline derivatives to introduce a more potent therapies.

The first type of drug designed using internet based tools using chloroquine as prototype drug having probable antimalarial activity as it consists of 4-aminoquinoline [15] pharmacophore. The structural analogues of chloroquine have been designed in such a way that it will show 
<smiles>CCN(CC)CCCC(C)Nc1ccnc2cc(Cl)ccc12</smiles>

Figure 6. Prototype molecule chloroquine having MolSoft drug likeness score of 1.17

more drug likeness score than the prototype molecule but having the same pharmacophore essential for the antimalarial activity. The side chain present at 4 position of chloroquine have been modified with alteration of halogen atom in some cases at position 8 to get increased drug likeness score with the MolSoft Drug Likeness and Molecular Property prediction tool. In case of designed molecules AM3, AM4 the chlorine molecule at position 8 have been replaced by $-\mathrm{F}$ atom to increase the MolSoft drug likeness score than the prototype molecule chloroquine. The list of designed chloroquine analogues with drug likeness scores, predicted toxicity and other molecular properties have been listed below. The position of $R^{1}$ and $R^{2}$ in the 4aminoquinolone ring (Figure 5) are modified in these designed molecules to get increased drug likeness score.

a. List of Designed Chloroquine Analogues with Molsoft Drug Likeness Scores and Predicted Molecular Properties

Drug likeness scores and molecular properties, as predicted by MolSoft, are marked with an asterisk $\left({ }^{*}\right)$.<smiles>CCCN(CCC)CCCCNc1ccnc2cc(Cl)ccc12</smiles>

Drug likeness* score 1.38 Molecule ID: AM1
Molecular properties* of AM1:

Molecular formula: $\mathrm{C}_{19} \mathrm{H}_{28} \mathrm{Cl} \mathrm{N}$

Molecular weight: 333.20

Number of HBA: 2

Number of HBD: 1

MolLogP : 5.90 (> 5)

MolLogS : -5.71 (in Log(moles/L)) 0.65 (in $\mathrm{mg} / \mathrm{L})$

MolPSA : $24.58 \mathrm{~A}^{2}$

MolVol : $343.53 A^{3}$

Number of stereo centers: 0<smiles>CCCN(CCC)CCCC(C)Nc1ccnc2cc(Cl)ccc12</smiles>

Drug likeness ${ }^{*}$ score 1.25

Molecule ID:AM2

Molecular properties* of AM2:

Molecular formula: $\mathrm{C}_{20} \mathrm{H}_{30} \mathrm{Cl} \mathrm{N}$

Molecular weight: 347.21

Number of HBA: 2

Number of HBD: 1

MolLogP : 5.35 (> 5)

MolLogS : -5.89 (in Log(moles/L)) 0.44 (in $\mathrm{mg} / \mathrm{L})$

MolPSA : $24.04 \mathrm{~A}^{2}$

MolVol : $359.14 A^{3}$

Number of stereo centers: 1<smiles>CCCN(CCC)CCCCNc1ccnc2cc(F)ccc12</smiles>

Drug likeness* score 1.23 Molecule ID:AM3 Molecular properties* of AM3:

Molecular formula: $\mathrm{C}_{19} \mathrm{H}_{28} \mathrm{~F} \mathrm{~N}_{3}$

Molecular weight: 317.23

Number of HBA: 2

Number of HBD: 1

MolLogP : $5.27(>5)$

MolLogS : -5.13 (in Log(moles/L)) 2.37 (in $\mathrm{mg} / \mathrm{L})$ 


\begin{tabular}{|l|l|l|l|l|l|}
\hline Molecule ID & cLogP value & Solubility & $\begin{array}{c}\text { Molecular } \\
\text { Weight }\end{array}$ & $\begin{array}{c}\text { Drug } \\
\text { Likeness }\end{array}$ & $\begin{array}{c}\text { Drug } \\
\text { Score }\end{array}$ \\
\hline AM1 & 4.89 & -4.22 & 333.0 & 3.27 & 0.59 \\
\hline AM2 & 5.3 & -4.60 & 347.0 & 5.56 & 0.53 \\
\hline AM3 & 4.34 & -3.8 & 317.0 & 0.89 & 0.60 \\
\hline AM4 & 4.74 & -4.18 & 331.0 & 3.36 & 0.61 \\
\hline
\end{tabular}

Table 1. OSIRIS Property explorer values of designed chloroquine analogues. All parameters in OSIRIS property explorer shows "green" colour for all designed drugs which indicates the drug confirm behavior of these designed chloroquine analogues.

MolPSA : $24.58 \mathrm{~A}^{2}$

MolVol : $332.26 \mathrm{~A}^{3}$

Number of stereo centers: 0<smiles>CCCN(CCC)CCCC(C)Nc1ccnc2cc(F)ccc12</smiles>

Drug likeness score* 1.20

Molecule ID: AM4

Molecular Properties* of AM4:

Molecular formula: $\mathrm{C}_{20} \mathrm{H}_{30} \mathrm{~F} \mathrm{~N}_{3}$

Molecular weight: 331.24

Number of HBA: 2

Number of HBD: 1

MolLogP : 4.72

MolLogS : -5.31 (in Log(moles/L)) 1.61 (in $\mathrm{mg} / \mathrm{L})$

MolPSA : $24.04 \mathrm{~A}^{2}$

MolVol : $347.87 A^{3}$

Number of stereo centers: 1

b. Phase I Metabolic site prediction using MetaPrint2D by setting the strictness of the fingerprint matching in "DEFAULT" and selecting model "ALL (Metabolite 2010.2)":

The color highlighting an atom indicates its normalized occurrence ratio
(NOR). A high NOR indicates a more frequently reported site of metabolism in the metabolite database. The normalized occurrence ratio does not indicate how likely a molecule is to be metabolised, but rather the relative likelihood of metabolism occurring at a particular site in the molecule, assuming it is metabolised. The Indication of colors which denotes predicted metabolic sites (see the Results Color Scheme on p. 39).

On the basis of predicted lazar toxicity it is clear that the molecules AM3 and AM4 are more potent than chloroquine,AM1 and AM2. But as the toxicity level of the drugs $A M 1$ and $A M 2$ have almost similar with chloroquine and in some cases the confidence value for the predicted toxicity is more than that of chloroquine (the confidence value for the non-carcinogenic property of AM1 and AM2 in case of SingleCellCall ${ }^{* *}$ and Mouse ${ }^{* *}$ parameters are more than that of the chloroquine) hence they are believed to be more potent than chloroquine as well.

\begin{tabular}{|l|l|}
\hline Red & $0.66<=\mathrm{NOR}<=1.00$ \\
\hline Orange & $0.33<=\mathrm{NOR}<0.66$ \\
\hline Green & $0.15<=\mathrm{NOR}<0.33$ \\
\hline White & $0.00<=\mathrm{NOR}<0.15$ \\
\hline Grey & Little/no data \\
\hline
\end{tabular}

Results Color Scheme 


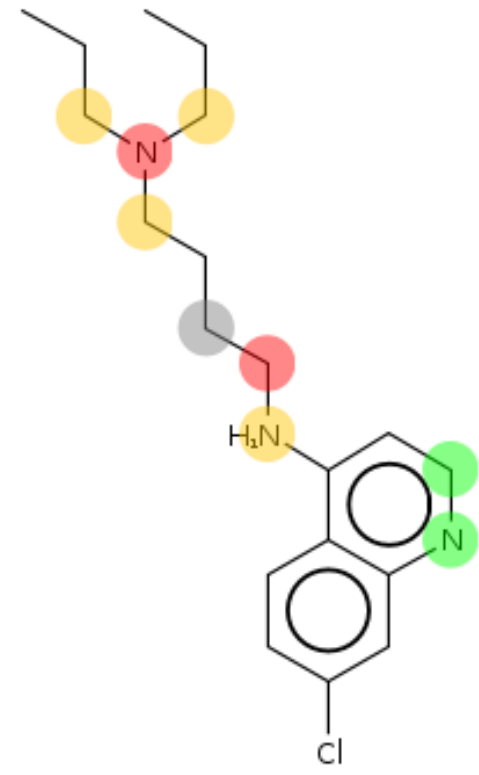

Figure 7a. Predicted Phase I metabolic sites of AM1.

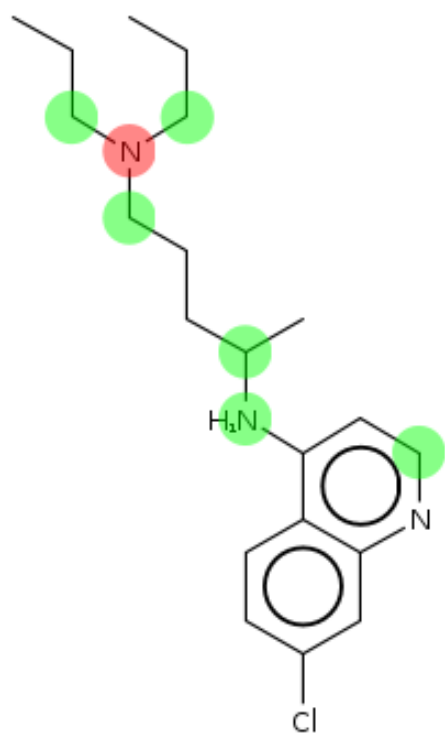

Figure 7b. Predicted Phase I metabolic sites of AM2.

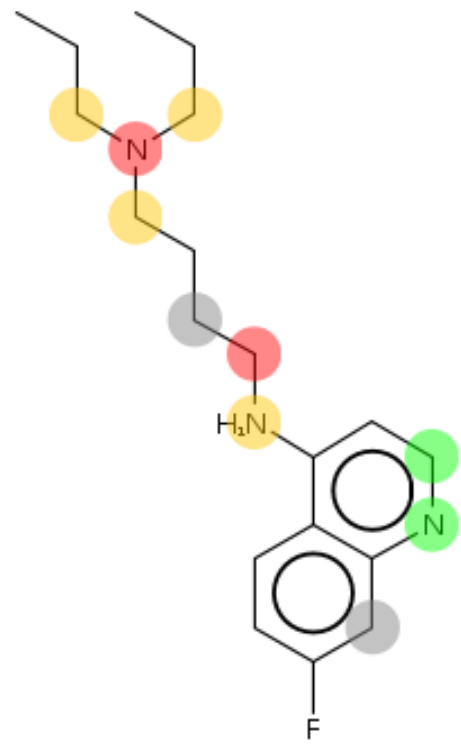

Figure 7c. Predicted Phase I metabolic sites of AM3.

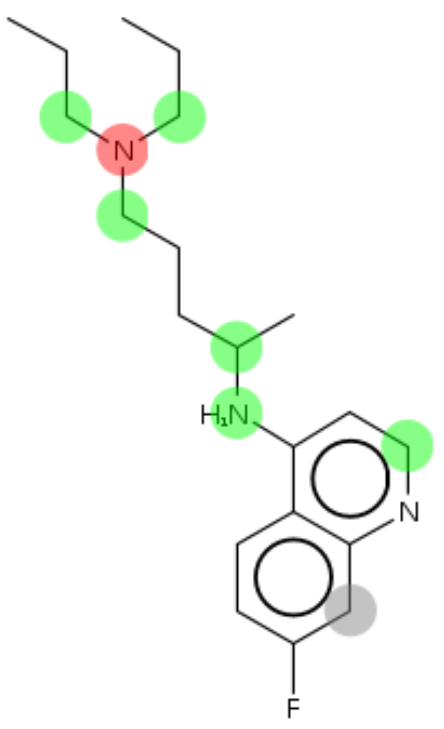

Figure 7d. Predicted Phase I metabolic sites of AM4. 


\begin{tabular}{|c|c|c|c|c|c|c|}
\hline $\begin{array}{l}\text { Molec } \\
\text { ule ID }\end{array}$ & $\begin{array}{c}\text { DSSTox } \\
\text { Carcinogeni } \\
\text { c Potency } \\
\text { DBS } \\
\text { MultiCellCall }\end{array}$ & $\begin{array}{l}\text { DSSTox } \\
\text { Carcinogenic } \\
\text { Potency DBS } \\
\text { Mutagenicity }\end{array}$ & $\begin{array}{c}\text { DSSTox } \\
\text { Carcinogenic } \\
\text { Potency DBS } \\
\text { Rat }\end{array}$ & $\begin{array}{c}\text { FDA v3b } \\
\text { Maximum } \\
\text { Recommended } \\
\text { Daily Dose } \\
\text { mmol }\end{array}$ & $\begin{array}{c}\text { DSSTox } \\
\text { Carcinogenic } \\
\text { Potency DBS } \\
\text { SingleCellCall }^{\star \star}\end{array}$ & $\begin{array}{c}\text { DSSTox } \\
\text { Carcinogeni } \\
\text { c Potency } \\
\text { DBS } \\
\text { Mouse }^{\star \star}\end{array}$ \\
\hline AM1 & $\begin{array}{l}\text { Carcinogen } \\
\text { Confidence: } \\
0.0219\end{array}$ & $\begin{array}{l}\text { Mutagenic } \\
\text { Confidence: } \\
0.375\end{array}$ & $\begin{array}{l}\text { Carcinogen } \\
\text { Confidence: } \\
0.0101\end{array}$ & $\begin{array}{l}0.017880721877 \\
6623 \\
\text { Confidence: } \\
0.143\end{array}$ & $\begin{array}{l}\text { Non-carcinogen } \\
\text { Confidence: } \\
0.0762\end{array}$ & $\begin{array}{l}\text { Non- } \\
\text { carcinogen } \\
\text { Confidence: } \\
0.0628\end{array}$ \\
\hline AM2 & $\begin{array}{l}\text { Carcinogen } \\
\text { Confidence: } \\
0.0104\end{array}$ & $\begin{array}{l}\text { Mutagenic } \\
\text { Confidence: } \\
0.375\end{array}$ & $\begin{array}{l}\text { Carcicnogen } \\
\text { Confidence: } \\
0.016\end{array}$ & $\begin{array}{l}0.015118320199 \\
0332 \\
\text { Confidence: } \\
0.141\end{array}$ & $\begin{array}{l}\text { Non-carcinogen } \\
\text { Confidence: } \\
0.0788\end{array}$ & $\begin{array}{l}\text { Non- } \\
\text { carcinogen } \\
\text { Confidence } \\
: 0.0427\end{array}$ \\
\hline AM3 & $\begin{array}{l}\text { Non- } \\
\text { Carcinogen } \\
\text { Confidence: } \\
0.0835\end{array}$ & $\begin{array}{l}\text { Mutagenic } \\
\text { Confidence: } \\
0.316\end{array}$ & $\begin{array}{l}\text { Non- } \\
\text { carcinogen } \\
\text { Confidence: } \\
0.0796\end{array}$ & $\begin{array}{l}0.011512717302 \\
3031 \\
\text { Confidence: } \\
0.101\end{array}$ & $\begin{array}{l}\text { Non-carcinogen } \\
\text { Confidence: } \\
0.0762\end{array}$ & $\begin{array}{l}\text { Non- } \\
\text { carcinogen } \\
\text { Confidence: } \\
0.0628\end{array}$ \\
\hline AM4 & $\begin{array}{l}\text { Non- } \\
\text { carcinogen } \\
\text { Confidence: } \\
0.0678\end{array}$ & $\begin{array}{l}\text { Mutagenic } \\
\text { Confidence: } \\
0.0316\end{array}$ & $\begin{array}{l}\text { Non- } \\
\text { carcinogen } \\
\text { Confidence: } \\
0.083\end{array}$ & $\begin{array}{l}0.012171034012 \\
6146 \\
\text { Confidence: } \\
0.124\end{array}$ & $\begin{array}{l}\text { Non-carcinogen } \\
\text { Confidence: } \\
0.0788\end{array}$ & $\begin{array}{l}\text { Non- } \\
\text { carcinogen } \\
\text { Confidence: } \\
0.0427\end{array}$ \\
\hline $\begin{array}{l}\text { Chloro } \\
\text {-quine }\end{array}$ & $\begin{array}{l}\text { Carcinogen } \\
\text { Confidence: } \\
0.0227\end{array}$ & $\begin{array}{l}\text { Mutagenic } \\
\text { Confidence: } \\
0.375\end{array}$ & $\begin{array}{l}\text { Carcinogen } \\
\text { Confidence: } \\
0.016\end{array}$ & $\begin{array}{l}0.016617933620 \\
0351 \\
\text { Confidence: } \\
0.147\end{array}$ & $\begin{array}{l}\text { Non-carcinogen } \\
\text { Confidence: } \\
0.0553\end{array}$ & $\begin{array}{l}\text { Non- } \\
\text { carcinogen } \\
\text { Confidence: } \\
0.0427\end{array}$ \\
\hline
\end{tabular}

Table 2. Predicted toxicity of chloroquine analogues using in-silico lazar toxicity prediction tool http://lazar.in-silico.de/predict.

\section{DESIGNED ARTEMISININ ANALOGUES AS ANTIMALARIAL AGENTS}

Artemisinin [16] (Fig. 8) is a drug that posses the most rapid action of all current drugs against Plasmodium falciparum malaria. To increase the potency (the main aim is to cure Artemisinin resistant malaria [17]) and make this drug more broad spectrum antimalarial agent the carbon at position 10 of Artemisinin is replaced by nitrogen with a side chain having a analogous chloroquine like side chain and a chlorine atom is attached with position 15 of Artemisinin. The new designed drug like molecules have been found to have more drug likeness score than that of the prototype drug Artemisinin (Artemisinin has a drug likeness score that of 1.22). The toxicity and metabolic sites of these designed drugs have been predicted using the toxicity, metabolic site prediction tools.

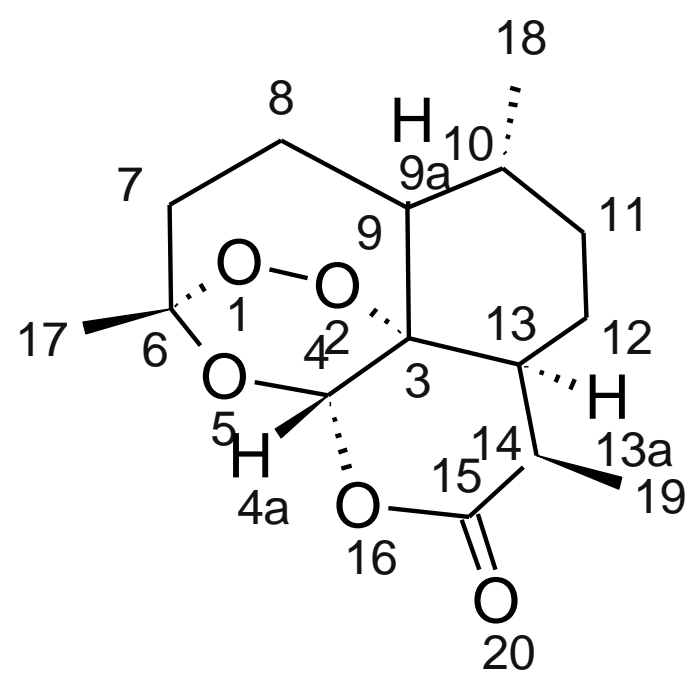

Figure 8. The prototype drug Artemisinin. 
a. List of Designed Artemisinin Analogues with MolSoft Drug Likeness Scores and Predicted Molecular Properties<smiles>CCC(CC)CC(C)CN1CC[C@H]2C(C)C(=O)O[C@H]3O[C@@]4(C)CCC1[C@@]23OO4</smiles>

Molecule ID: AMM1

Drug-likeness score of AMM1: 1.97 Molecular Properties of AMM1:

Molecular formula: $\mathrm{C}_{22} \mathrm{H}_{37} \mathrm{~N} \mathrm{O}_{5}$

Molecular weight: 395.27

Number of HBA: 6

Number of HBD: 0

MolLogP : 5.46 (> 5)

MolLogS : -2.52 (in Log(moles/L)) 1202.47 (in $\mathrm{mg} / \mathrm{L}$ )

MolPSA : $51.18 \mathrm{~A}^{2}$

MolVol : $445.00 \mathrm{~A}^{3}$

Number of stereo centers: 7<smiles>CCN(CC)CC(C)CN1CC[C@H]2C(C)C(=O)O[C@@H]3O[C@@]4(C)CCC1[C@@]2(OO)[C@@H]34</smiles>

Molecule ID: AMM2

Drug-likeness score of AMM2: 1.90

Molecular Properties of AMM2:

Molecular formula: $\mathrm{C}_{21} \mathrm{H}_{36} \mathrm{~N}_{2} \mathrm{O}_{5}$

Molecular weight: 396.26

Number of HBA: 7

Number of HBD: 0

MolLogP : 3.71

MolLogS : -1.10 (in Log(moles/L)) 31431.52 (in $\mathrm{mg} / \mathrm{L}$ )

MolPSA : $55.19 \mathrm{~A}^{2}$

MolVol : $443.65 A^{3}$

Number of stereo centers: 7<smiles>CCN(CC)CC(C)CN1CC[C@H]2[C@@H](C)[C@H](Cl)O[C@H]3O[C@]4(C)CCC1[C@@]23OO4</smiles>

Molecule ID:AMM3

Drug likeness model score of AMM3:1.46

Molecular Properties of AMM3:

Molecular formula: $\mathrm{C}_{21} \mathrm{H}_{37} \mathrm{Cl} \mathrm{N}_{2} \mathrm{O}_{4}$

Molecular weight: 416.24

Number of HBA: 6

Number of HBD: 0

MolLogP : 4.23

MolLogS : -1.62 (in Log(moles/L)) 10018.30

(in $\mathrm{mg} / \mathrm{L}$ )

MolPSA : $42.77 \mathrm{~A}^{2}$

MolVol : $446.57 \mathrm{~A}^{3}$

Number of stereo centers: 8

Artemisinin and all its analogues have shown mutagenic, tumorigenic and irritant property as it shows in "red colour" in OSIRIS Property Explorer but all of their designed analogues have more drug score than that of Artemisinin hence it is predicted that these newly designed drug like molecules have much more potency than that of the prototype drug Artemisinin.

b. Phase I Metabolic site prediction using MetaPrint2D by setting the strictness of the fingerprint matching in "DEFAULT" and selecting model "ALL (Metabolite 2010.2)"

The color highlighting an atom indicates its normalized occurrence ratio (NOR). A high NOR indicates a more frequently reported site of metabolism in the metabolite database. The normalized occurrence ratio does not indicate how likely 


\begin{tabular}{|c|c|c|c|c|c|}
\hline Molecule ID & cLogP value & Solubility & $\begin{array}{c}\text { Molecular } \\
\text { Weight }\end{array}$ & $\begin{array}{c}\text { Drug } \\
\text { Likeness }\end{array}$ & Drug Score \\
\hline AMM1 & 4.62 & -3.93 & 395.0 & 1.71 & 0.12 \\
\hline AMM2 & 2.55 & -2.41 & 396.0 & 3.37 & 0.17 \\
\hline AMM3 & 4.08 & -2.97 & 416.0 & 0.53 & 0.12 \\
\hline Prototype drug, Artemisinin & 2.37 & -3.29 & 282.0 & -1.97 & 0.10 \\
\hline
\end{tabular}

Table 3. OSIRIS Property explorer values of designed Artemisinin analogues.

\begin{tabular}{|c|c|c|c|c|c|c|}
\hline $\begin{array}{l}\text { Molecule } \\
\text { ID }\end{array}$ & $\begin{array}{l}\text { DSSTox } \\
\text { Carcinogenic } \\
\text { Potency DBS } \\
\text { MultiCellCall }\end{array}$ & $\begin{array}{l}\text { DSSTox } \\
\text { Carcinogenic } \\
\text { Potency DBS } \\
\text { Mutagenicity }\end{array}$ & $\begin{array}{l}\text { DSSTox } \\
\text { Carcino- } \\
\text { genic } \\
\text { Potency } \\
\text { DBS Rat }\end{array}$ & $\begin{array}{l}\text { FDA v3b } \\
\text { Maximum } \\
\text { Recommend- } \\
\text { ed Daily Dose } \\
\text { mmol }\end{array}$ & $\begin{array}{l}\text { DSSTox } \\
\text { Carcinogenic } \\
\text { Potency DBS } \\
\text { SingleCellCall }^{\star \star}\end{array}$ & $\begin{array}{l}\text { DSSTox } \\
\text { Carcinogen } \\
\text { ic Potency } \\
\text { DBS } \\
\text { Mouse }^{\star \star}\end{array}$ \\
\hline AMM1 & $\begin{array}{l}\text { Non- } \\
\text { Carcinogen } \\
\text { Confidence } \\
: 0.0647\end{array}$ & $\begin{array}{l}\text { Non- } \\
\text { Mutagenic } \\
\text { Confidence: } \\
0.133\end{array}$ & $\begin{array}{l}\text { Non- } \\
\text { Carcinogen } \\
\text { Confidence } \\
: \\
0.0637\end{array}$ & $\begin{array}{l}0.0013277759 \\
7200338 \\
\text { Confidence } \\
: 0.1\end{array}$ & $\begin{array}{l}\text { Non-carcinogen } \\
\text { Confidence: } \\
0.0617\end{array}$ & $\begin{array}{l}\text { Non- } \\
\text { carcinogen } \\
\text { Confidence: } \\
0.12\end{array}$ \\
\hline AMM2 & $\begin{array}{l}\text { Non- } \\
\text { Carcinogen } \\
\text { Confidence: } \\
0.0647\end{array}$ & $\begin{array}{l}\text { Non- } \\
\text { Mutagenic } \\
\text { Confidence: } \\
0.133\end{array}$ & $\begin{array}{l}\text { Non- } \\
\text { Carcicnoge } \\
\mathrm{n} \\
\text { Confidence } \\
\vdots \\
0.0637 \\
\end{array}$ & $\begin{array}{l}0.0014508306 \\
7169408 \\
\text { Confidence: } \\
0.115\end{array}$ & $\begin{array}{l}\text { Non-carcinogen } \\
\text { Confidence: } \\
0.0617\end{array}$ & $\begin{array}{l}\text { Non- } \\
\text { carcinogen } \\
\text { Confidence: } \\
0.12\end{array}$ \\
\hline AMM3 & $\begin{array}{l}\text { Non- } \\
\text { Carcinogen } \\
\text { Confidence: } \\
0.0854\end{array}$ & $\begin{array}{l}\text { Non- } \\
\text { Mutagenic } \\
\text { Confidence: } \\
0.0837\end{array}$ & $\begin{array}{l}\text { Non- } \\
\text { carcinogen } \\
\text { Confidence } \\
\vdots \\
0.0682\end{array}$ & $\begin{array}{l}0.0014571756 \\
9177769 \\
\text { Confidence: } \\
0.114\end{array}$ & $\begin{array}{l}\text { Non-carcinogen } \\
\text { Confidence: } \\
0.0535\end{array}$ & $\begin{array}{l}\text { Non- } \\
\text { carcinogen } \\
\text { Confidence: } \\
0.114\end{array}$ \\
\hline Artemisinin & $\begin{array}{l}\text { Non- } \\
\text { Carcinogen } \\
\text { Confidence: } \\
0.0823\end{array}$ & $\begin{array}{l}\text { Non- } \\
\text { Mutagenic } \\
\text { Confidence: } \\
0.158\end{array}$ & $\begin{array}{l}\text { Non- } \\
\text { Carcinogen } \\
\text { Confidence } \\
\vdots \\
0.0682\end{array}$ & $\begin{array}{l}0.0005939950 \\
23800918 \\
\text { Confidence: } \\
0.112\end{array}$ & $\begin{array}{l}\text { Non-carcinogen } \\
\text { Confidence: } \\
0.0679\end{array}$ & $\begin{array}{l}\text { Non- } \\
\text { carcinogen } \\
\text { Confidence: } \\
0.0951\end{array}$ \\
\hline
\end{tabular}

Table 4. Predicted toxicity of Artemisinin analogues using in-silico lazar toxicity prediction tool http://lazar.in-silico.de/predict

a molecule is to be metabolised, but rather the relative likelihood of metabolism occurring at a particular site in the molecule, assuming it is metabolised.

All the designed drug like molecules taking the pharmacophore of lamivudine are found to have more drug score than that of the prototype drug lamivudine which leads to confirm that all newly drug like molecules might have increased and more potent activity than that of lamivudine. c. Phase I Metabolic site prediction using MetaPrint2D by setting the strictness of the fingerprint matching in "DEFAULT" and selecting model "ALL (Metabolite 2010.2)"

The color highlighting an atom indicates its normalized occurrence ratio (NOR). A high NOR indicates a more frequently reported site of metabolism in the metabolite database. The normalized occurrence ratio does not indicate how likely 
a molecule is to be metabolised, but rather the relative likelihood of metabolism occurring at a particular site in the molecule, assuming it is metabolized. (See p. 39 for the Results Color Scheme.)

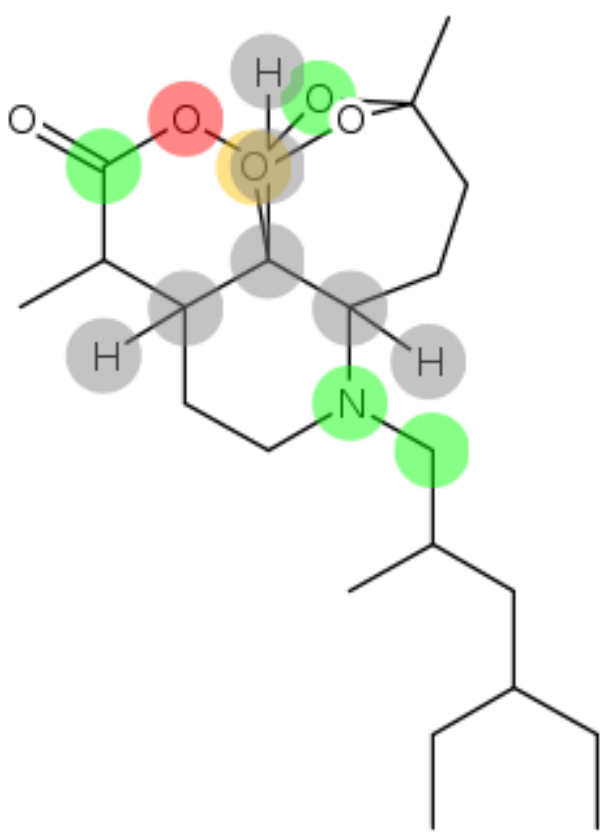

Figure 8a. Predicted phase I metabolic site of AMM1.

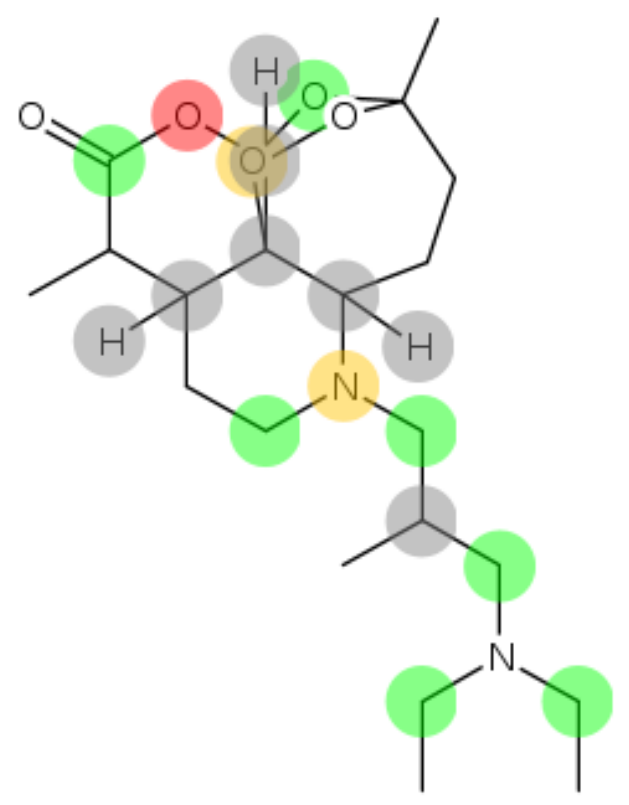

Figure 8b. Predicted Phase I metabolic site of AMM2.

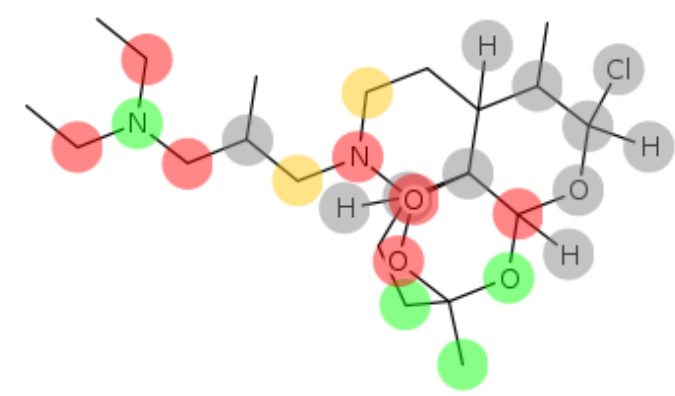

Figure 8c. Predicted Phase I metabolic site of AMM3.

All designed Artemisinin analogues have been predicted as non-carcinogen as well as non-mutagenic by the internet based lazar toxicity prediction tool this confirms that the rational and effective drug like molecules have been designed by SAR and pharmacophore study.

\section{DESIGN OF SOME LAMIVUDINE DERIVATIVES AS POTENT ANTI- RETROVIRAL AGENTS}

Lamivudine is a potent nucleoside analogue reverse transcriptase inhibitor [18]. To increase the potency of lamivudine as anti-HIV agent the $-\mathrm{R}$ part of lamivudine (Fig. 9) is substituted to get more potent designed drug like molecule having increased drug likeness score in MolSoft drug likeness and property explorer tool. The prototype drug lamivudine has a drug likeness score of 1.05 and the designed drug like molecules have greater drug likeness score that of lamivudine

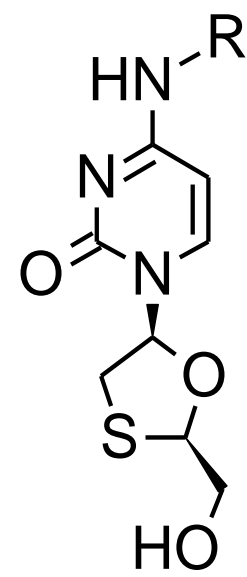

Figure 9. The pharmacophore of lamivudine. 


\begin{tabular}{|c|c|c|c|c|c|}
\hline Molecule ID & cLogP value & Solubility & $\begin{array}{c}\text { Molecular } \\
\text { Weight }\end{array}$ & Drug Likeness & Drug Score \\
\hline LMA1 & 0.0 & -1.57 & 257.0 & 1.27 & 0.51 \\
\hline LMA2 & -0.21 & -0.91 & 257.0 & 2.34 & 0.55 \\
\hline LMA3 & 4.08 & -2.04 & 269.0 & 1.46 & 0.51 \\
\hline $\begin{array}{c}\text { Prototype drug, } \\
\text { Lamivudine }\end{array}$ & 2.37 & -1.36 & 229.0 & -2.12 & 0.26 \\
\hline
\end{tabular}

Table 5. OSIRIS Property explorer values of designed Lamivudine derivatives.

a. List of designed Lamivudine Analogues with MolSoft Drug likeness Scores and Predicted Molecular Properties<smiles>CCNc1ccn([C@H]2CSC(CO)O2)c(=O)n1</smiles>

Molecule ID: LMA1

Drug-likeness score of LMA1: 1.16

Molecular Properties of LMA1:

Molecular formula: $\mathrm{C}_{10} \mathrm{H}_{15} \mathrm{~N}_{3} \mathrm{O}_{3} \mathrm{~S}$

Molecular weight: 257.08

Number of HBA: 5

Number of HBD: 2

MolLogP : 0.35

MolLogS : -2.12 (in Log(moles/L)) 1955.97

(in $\mathrm{mg} / \mathrm{L}$ )

MolPSA : $62.24 \mathrm{~A}^{2}$

MolVol : $256.18 A^{3}$

Number of stereo centers: 2<smiles>CN(C)c1ccn([C@H]2CS[C@@H](CO)O2)c(=O)n1</smiles>

Molecule ID:LMA2

Drug-likeness score of LMA2: 1.23

Molecular Properties and Drug-likeness:

Molecular formula: $\mathrm{C}_{10} \mathrm{H}_{15} \mathrm{~N}_{3} \mathrm{O}_{3} \mathrm{~S}$

Molecular weight: 257.08

Number of HBA: 5

Number of HBD: 1

MolLogP : -0.71

MolLogS : -1.81 (in Log(moles/L)) 3975.81

(in $\mathrm{mg} / \mathrm{L}$ )

MolPSA : $53.16 \mathrm{~A}^{2}$

MolVol : $259.27 \mathrm{~A}^{3}$

Number of stereo centers: 2 
<smiles>O=c1nc(NC2CC2)ccn1[C@H]1CSC(CO)O1</smiles>

Molecule ID:LMA3

Drug-likeness score of LMA3: 1.30

Molecular Properties and Drug-likeness:

Molecular formula: $\mathrm{C}_{11} \mathrm{H}_{15} \mathrm{~N}_{3} \mathrm{O}_{3} \mathrm{~S}$

Molecular weight: 269.08

Number of HBA: 5

Number of HBD: 2

MolLogP : 0.17

MolLogS : -2.15 (in Log(moles/L)) 1885.47

(in $\mathrm{mg} / \mathrm{L}$ )

MolPSA : $62.37 \mathrm{~A}^{2}$

MolVol : $272.08 \mathrm{~A}^{3}$

All the designed drug like molecules taking the pharmacophore of lamivudine are found to have more drug score than that of the prototype drug lamivudine which leads to confirm that all newly drug like molecules might have increased and more potent activity than that of lamivudine.

b. Phase I Metabolic Site Prediction using Metaprint2d by Setting the Strictness of the Fingerprint Matching in "DEFAULT" and Selecting Model "ALL (Metabolite 2010.2)"

The color highlighting an atom indicates its normalized occurrence ratio (NOR). A high NOR indicates a more frequently reported site of metabolism in the metabolite database. The normalized occurrence ratio does not indicate how likely a molecule is to be metabolized, but rather the relative likelihood of metabolism occurring at a particular site in the molecule, assuming it is metabolized.

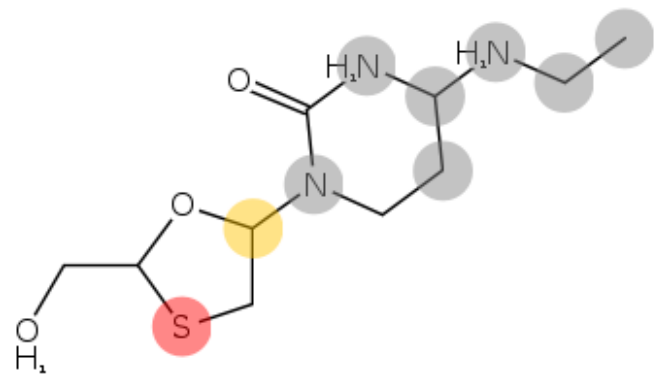

Figure 9a. Predicted Phase I metabolic site. of LMA1

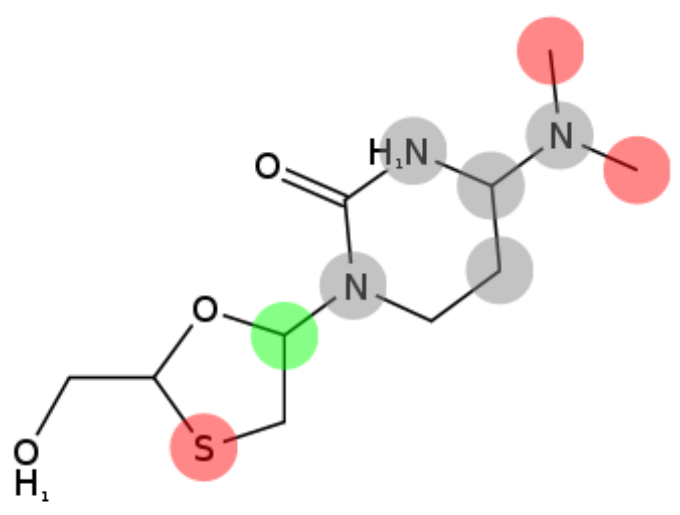

Figure 9b. Predicted Phase I metabolic site of LMA2.

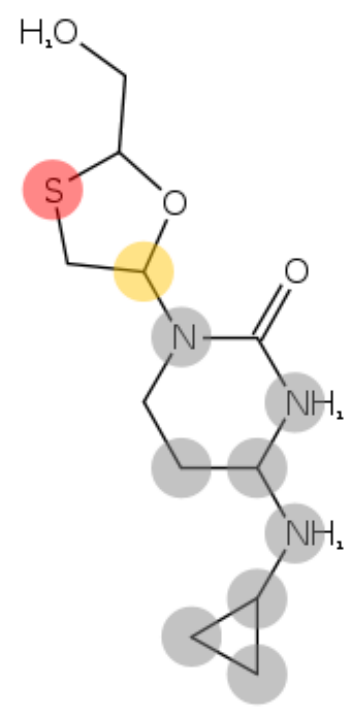

Figure 9c. Predicted Phase I metabolic site of LMA3. 


\begin{tabular}{|c|c|c|c|c|c|c|}
\hline $\begin{array}{l}\text { Molecule } \\
\text { ID }\end{array}$ & $\begin{array}{l}\text { DSSTox } \\
\text { Carcinogeni } \\
\text { c Potency } \\
\text { DBS } \\
\text { MultiCellCall }\end{array}$ & $\begin{array}{l}\text { DSSTox } \\
\text { Carcinogenic } \\
\text { Potency DBS } \\
\text { Mutagenicity }\end{array}$ & $\begin{array}{l}\text { DSSTox } \\
\text { Carcinoge } \\
\text { nic } \\
\text { Potency } \\
\text { DBS Rat } \\
\end{array}$ & $\begin{array}{l}\text { FDA v3b } \\
\text { Maximum } \\
\text { Recommend } \\
\text { ed Daily } \\
\text { Dose mmol } \\
\end{array}$ & $\begin{array}{l}\text { DSSTox } \\
\text { Carcinogenic } \\
\text { Potency DBS } \\
\text { SingleCellCall }^{\star *}\end{array}$ & $\begin{array}{l}\text { DSSTox } \\
\text { Carcinogenic } \\
\text { Potency DBS }_{\text {Mouse }^{\star \star}}\end{array}$ \\
\hline LMA1 & $\begin{array}{l}\text { Carcinogen } \\
\text { Confidence: } \\
0.317\end{array}$ & $\begin{array}{l}\text { Non- } \\
\text { Mutagenic } \\
\text { Confidence: } \\
0.005\end{array}$ & $\begin{array}{l}\text { Carcinogen } \\
\text { Confidence: } \\
0.0744\end{array}$ & $\begin{array}{l}0.0218096608 \\
207519 \\
\text { Confidence: } \\
0.596\end{array}$ & $\begin{array}{l}\text { Carcinogen } \\
\text { Confidence: } \\
0.106\end{array}$ & $\begin{array}{l}\text { Carcinogen } \\
\text { Confidence: } \\
0.363\end{array}$ \\
\hline LMA2 & $\begin{array}{l}\text { Carcinogen } \\
\text { Confidence: } \\
0.0251\end{array}$ & $\begin{array}{l}\text { Non- } \\
\text { Mutagenic } \\
\text { Confidence: } \\
0.0503\end{array}$ & $\begin{array}{l}\text { Non- } \\
\text { Carcicnoge } \\
\mathrm{n} \\
\text { Confidence: } \\
0.0276\end{array}$ & $\begin{array}{l}0.1148336288 \\
75105 \\
\text { Confidence: } \\
0.0698\end{array}$ & $\begin{array}{l}\text { Non-carcinogen } \\
\text { Confidence: } \\
0.0291\end{array}$ & $\begin{array}{l}\text { Non-carcinogen } \\
\text { Confidence: } \\
0.0565\end{array}$ \\
\hline LMA3 & $\begin{array}{l}\text { Carcinogen } \\
\text { Confidence: } \\
0.0166\end{array}$ & $\begin{array}{l}\text { Mutagenic } \\
\text { Confidence: } \\
0.0242\end{array}$ & $\begin{array}{l}\text { Carcinogen } \\
\text { Confidence: } \\
0.0905\end{array}$ & $\begin{array}{l}0.0218096608 \\
207519 \\
\text { Confidence: } \\
0.596\end{array}$ & $\begin{array}{l}\text { Carcinogen } \\
\text { Confidence: } \\
0.0644\end{array}$ & $\begin{array}{l}\text { Carcinogen } \\
\text { Confidence: } \\
0.293\end{array}$ \\
\hline Lamivudine & $\begin{array}{l}\text { Carcinogen } \\
\text { Confidence: } \\
0.0317\end{array}$ & $\begin{array}{l}\text { Mutagenic } \\
\text { Confidence: } \\
0.005\end{array}$ & $\begin{array}{l}\text { Carcinogen } \\
\text { Confidence: } \\
0.0744\end{array}$ & $\begin{array}{l}0.0218096608 \\
207519 \\
\text { Confidence: } \\
0.596\end{array}$ & $\begin{array}{l}\text { Carcinogen } \\
\text { Confidence: } \\
0.106\end{array}$ & $\begin{array}{l}\text { Carcinogen } \\
\text { Confidence: } \\
0.43\end{array}$ \\
\hline
\end{tabular}

Table 6. Predicted toxicity of Artemisinin analogues using in-silico lazar toxicity prediction tool http://lazar.in-silico.de/predict

From predicted lazar toxicity it is clear that the most effective design drug like molecule is LMA2 which posses lower predicted toxicity level as compare with other designed analogues and of lamivudine. But all other design molecules will have be more effective than that of lamivudine as LMA1 and LMA3 as both of these drugs have lower predicted lazar toxicity than that of lamivudine (as compared by the "confidence" value generated by the lazar toxicity prediction tool, lower confidence value of predicted toxicity of LMA1 and LMA3 than that of prototype drug lamivudine suggests that they are less toxic than lamivudine).

\section{CONCLUSIONS}

These entire designed drug like molecules designed on the basis of SAR and pharmacophore study predicted to be more effective and potent in nature than that of all protype molecules. The predicted metabolic sites will be beneficial for computational chemists for docking analysis of these drugs and in choosing suitable targets. The internet based tools used in this study for calculating drug score, drug likeness, toxicity and other drug like and molecular properties are easy to handle and user friendly. Designing of these drug like molecules by the pharmacophore study and prediction of drug like properties of these molecules by the internet based tools hope to speed up basic drug design research as all these tools are user friendly. Currently work is going on the development of a "Miracle Molecule" by the use of internet based drug design tools which can be act as an antimalarial, antiviral, antiretroviral, anticancer, antibacterial agent as it will contain all the pharmacophores necessary for these activities and the work will be reported in near future.

\section{ACKNOWLEDGEMENTS}

I am very much thankful to all my friends of Birla Institute of Technology, Mesra, Ranchi835215 for their healthy criticism and constant encouragement.

\section{REFERENCES}

1. Marshall GR (1987) Computer-Aided Drug Design, Annual Review of Pharmacology and Toxicology, Vol. 27: 
193-213, DOI: 10.1146/annurev.pa. 27. 040187.001205

2. Chen, G. S. and Chern, J.-W. (2006) Computer-Aided Drug Design, in Drug Discovery Research: New Frontiers in the Post-Genomic Era (ed Z. Huang), John Wiley \& Sons, Inc., Hoboken, NJ, USA. DOI: 10.1002/9780470131862.ch4

3. Ooms $F(2000)$ Molecular Modelling and Computer Aided Drug Design. Examples of their Applications in Medicinal Chemistry, Current Medicinal Chemistry, Vol. 7(2) 141-158, DOI: http://dx.doi.org $/ 10.2174 / 0929867003375317$.

4. Guner, O.F.(2002) History and Evolution of the Pharmacophore Concept in Computer-Aided Drug Design, Current Topics in Medicinal Chemistry, Vol. 2(12) pp 1321-1332, DOI: http://dx.doi.org/ $10.2174 / 1568026023392940$.

5. Lu IL, Mahindroo N, Liang PH, Peng YH, Kuo CJ, Tsai KC, Hsieh HP, Chao YS, Wu SY.(2006) Structure-based drug design and structural biology study of novel nonpeptide inhibitors of severe acute respiratory syndrome coronavirus main protease, J Med Chem., 49(17) pp 5154-61.

6. Güner OF, ed. (1999). Pharmacophore perception, development, and use in drug design. LaJolla, CA: International University Line. ISBN 0-9636817-6-1.

7. C.A. Lipinski; F. Lombardo; B.W. Dominy and P.J. Feeney (2001). "Experimental and computational approaches to estimate solubility and permeability in drug discovery and development settings". Adv Drug Del
Rev 46 pp 3-26. DOI:10.1016/S0169409X(00)00129-0.

8. http://www.molsoft.com/mprop/

9. JME courtesy of Dr. Peter Ertl, Novartis Pharma AG, Basel, Switzerland

10. http://lazar.in-silico.de/predict

11. http://www.cheminformatics.ch/property Explorer/

12. http://www-metaprint2d.ch.cam.ac.uk/

13. Chloroquine. (2012, April 15). In Wikipedia, The Free Encyclopedia. Retrieved 07:34, April 26, 2012, from http://en.wikipedia.org/w/index.php?title $=$ Chloroquine\&oldid $=487475543$.

14. Martin RE, Marchetti RV, Cowan Al et al.(September 2009). "Chloroquine transport via the malaria parasite's chloroquine resistance transporter". Science 325(5948) pp1680-2.

15. Bourne SA, De Villiers K, Egan TJ (2006). "Three 4-aminoquinolines of antimalarial interest" Acta Crystallogr C 62 (Pt 2): o53-7. DOI:10.1107/ S0108270105041235

16. Artemisinin. In Wikipedia, The Free Encyclopedia. Retrieved 07:37, April 26, 2012, from http://en.wikipedia.org/w/ index.php?title $=$ Artemisinin \&oldid $=4858$ 47862

17. Noedl H, Se Y, Schaecher K, Smith BL, Socheat D, Fukuda MM (December 2008). "Evidence of artemisinin-resistant malaria in western Cambodia". N. Engl. J. Med. 359 (24): 2619-20. doi:10.1056/NEJMc0805011

18. Lamivudine. (2012, April 15). In Wikipedia, The Free Encyclopedia. Retrieved 07:41, April 26, 2012, from http://en.wikipedia.org/w/index.php?title $=$ Lamivudine\&oldid $=487580017$ 